\title{
Pengaruh Penerapan Pendekatan Reciprocal Teaching terhadap Kemampuan Komunikasi Matematis ditinjau dari Kemandirian Belajar Siswa SMP
}

\author{
Feby Rendani, Hartono \\ Program Studi Pendidikan Matematika, Universitas Islam Negeri Sultan Syarif Kasim Riau \\ Jl. H. R. Soebrantas KM. 15.5, Pekanbaru, Indonesia, 29283 \\ e-mail: febbyrendani@gmail.com
}

\begin{abstract}
ABSTRAK. Penelitian ini bertujuan untuk menyelidiki perbedaan kemampuan komunikasi matematis antara siswa yang diajar dengan pendekatan Reciprocal Teaching dengan siswa yang diajar dengan pembelajaran konvensional jika ditinjau dari kemandirian belajar siswa SMP Negeri 2 Bangkinang Kota. Penelitian ini merupakan penelitian quasi eksperimen serta desain yang digunakan adalah The Nonequivalent Pretest-Posttest Control Group Design. Teknik analisis data menggunakan uji-t dan anova dua arah (Two-Way Anova). Berdasarkan hasil analis data dapat diambil kesimpulan bahwa: 1) Terdapat perbedaan kemampuan komunikasi matematis antara siswa yang diajar dengan pendekatan Reciprocal Teacing dan siswa yang diajar dengan pembelajaran konvensional. Hasilnya di peroleh bahwa $t_{\text {hitung }}>t_{\text {tabel }}$ pada taraf signifikan $5 \%$ diperoleh $3,53>2,01$. 2) Terdapat perbedaan kemampuan komunikasi matematis antara siswa yang diajar dengan pendekatan Reciprocal Teaching dan siswa yang diajar dengan pembelajaran konvensional jika ditinjau dari kemandirian belajar. Hasilnya diperoleh bahwa $F(B)_{\text {hitung }}>F(B)_{\text {tabel }}$ pada taraf signifikan $5 \%$ diperoleh $24,46>3,20$ dan 3) Tidak terdapat interaksi faktor pendekatan pembelajaran dan faktor kemandirian belajar terhadap kemampuan komunikasi matematis siswa. Hasilnya diperoleh bahwa $F(A \times B)_{\text {hitung }}<F(A \times B)_{\text {tabel }}$ pada taraf signifikan $5 \%$ diperoleh $1,41<3,20$. Dengan demikian, secara umum dapat disimpulkan bahwa pendekatan Reciprocal Teaching berpengaruh terhadap kemampuan komunikasi matematis yang ditinjau dari kemandirian belajar siswa SMP Negeri 2 Bangkinang Kota.
\end{abstract}

Kata kunci: pendekatan reciprocal teaching, kemampuan komunikasi matematis, kemandirian belajar

\section{PENDAHULUAN}

Komunikasi dibutuhkan hampir diseluruh kegiatan manusia, terutama dalam bidang pendidikan. Van de Walle (2006) menyatakan bahwa cara terbaik untuk berhubungan dengan suatu ide adalah dengan mencoba menyampaikan ide tersebut adalah dengan menyampaikan ide tersebut dengan orang lain, hal ini juga berlaku dalam pembelajaran matematika. Komunikasi diperlukan untuk memahami ide matematika secara benar. Kemampuan komunikasi yang lemah akan berakibat pada lemahnya kemampuan-kemampuan matematika yang lain (Qohar, 2010: 6).

Berdasarkan Lampiran Permendikbud Nomor 58 Tahun 2014 tentang Kurikulum SMP dijelaskan bahwa salah satu tujuan pembelajaran matematika adalah agar siswa dapat mengkomunikasikan gagasan matematika dengan menggunakan kalimat lengkap, simbol, tabel, diagram, atau media lain untuk memperjelas keadaan atau masalah. Dengan demikian, 
berdasarkan lampiran permendikbud tersebut jelas bahwa kemampuan komunikasi matematis merupakan aspek penting yang harus dikembangkan dalam diri siswa.

Berdasarkan hasil survei Trends in International Mathematics and Science Study (TIMSS) pada tahun 2015, Indonesia berada pada peringkat 45 dari 50 negara dengan skor kemampuan matematika adalah 397. Berdasarkan hasil survei TIMSS tersebut dapat diketahui bahwa siswa Indonesia menguasai soal-soal rutin dan bersifat sederhana, sedangkan soal-soal yang memerlukan kemampuan mengintegrasikan informasi, menarik kesimpulan serta menggenalisir pengetahuan yang dimiliki ke hal-hal lain masih memerlukan penguatan. Selanjutnya, hasil penelitian Tim Pusat Pengembangan Penataran Guru Matematika juga mengungkapkan bahwa di beberapa wilayah Indonesia yang berbeda, sebagian besar siswa kesulitan dalam menerjemahkan soal kehidupan sehari-hari ke dalam model matematika (Shadiq dalam Agustyaningrum, 2011: 377). Hal ini menunjukkan bahwa kemampuan komunikasi matematis siswa Indonesia masih kurang baik. Berikutnya berdasarkan hasil tes dengan memberikan dua soal kemampuan komunikasi matematis pada siswa kelas VII SMP Negeri 2 Bangkinang Kota diperoleh data bahwa pencapaian kemampuan komunikasi matematis siswa untuk soal pertama hanya sebesar $35,55 \%$ sedangkan untuk soal kedua sebesar 40,37\%. Berdasarkan hasil tes tersebut dapat diketahui bahwa kemampuan komunikasi matematis siswa SMP Negeri 2 Bangkinang Kota belum bisa dikatakan baik.

Selama ini guru telah menggunakan berbagai cara untuk mengembangkan kemampuan komunikasi matematis, seperti metode ceramah, tanya jawab namun usaha tersebut belum memberikan hasil yang cukup memuaskan terhadap kemampuan komunikasi matematis siswa. Oleh karena itu, guru harus mampu memilih pendekatan pembelajaran yang dapat melatih kemampuan komunikasi matematis siswa. Salah satu pendektaan yang dapat digunakan untuk melatih komunikasi matematis siswa adalah dengan menggunakan pendekatan Reciprocal Teaching. Pendekatan Reciprocal Teaching adalah suatu penyampaian materi ajar dengan guru menunjuk seorang siswa untuk menggantikan perannya sebagai guru dan bertindak sebagai pemimpin kelompok, sedangkan guru beralih peran dalam kelompok sebagai motivator, mediator, pelatih memberikan dukungan, umpan balik, serta semangat bagi siswa (Istarani dan Ridwan, 2014: 185). Dalam Reciprocal Teaching ditanamkan empat strategi pemahaman mandiri kepada siswa, yaitu merangkum (summarizing), menyusun pertanyaan (questioning), mengklarifikasi pengetahuan yang telah diperoleh (clarifying), kemudian memprediksi materi selanjutnya (predicting) (Palinscar dan Brown, 1984).

Selain faktor pendekatan pembelajaran, kemandirian belajar juga menentukan hasil belajar. Menurut Sumarmo (dalam Bistari, 2010: 17) individu yang belajar matematika dituntut untuk memiliki disposisi matematis yang tinggi, sehingga bisa menghasilkan kemampuan berfikir matematis yang diharapkan. Disposisi matematis tersebut mengacu pada Lampiran Permendikbud No. 65 Tahun 2013 tentang standar proses, menyatakan bahwa proses pembelajaran pada satuan pendidikan diselenggarakan salah satunya adalah dengan kemandirian. Dengan demikian, siswa yang memiliki kemandirian belajar yang tinggi dapat menghasilkan kemampuan berfikir matematis yang diharapkan, salah satunya adalah kemampuan komunikasi matematis.

Berdasarkan uraian-uraian yang telah dijelaskan, maka sangat diperlukan penelitian mengenai pengaruh penerapan pendekatan reciprocal teaching terhadap kemampuan komunikasi matematis ditinjau dari kemandirian belajar siswa SMP. Dengan demikian penelitian ini bertujuan untuk mengetahui: (1) apakah terdapat perbedaan kemampuan komunikasi matematis antara 
siswa yang diajar dengan pendekatan reciprocal teaching dengan siswa yang diajar dengan pembelajaran konvensional, (2) apakah terdapat perbedaan kemampuan komunikasi matematis antara siswa yang diajar dengan pendekatan reciprocal teaching dengan siswa yang diajar dengan pembelajaran konvensional jika ditinjau dari kemandirian belajar, (3) apakah terdapat interaksi faktor pendekatan pembelajaran dengan faktor kemandirian belajar terhadap kemampuan komunikasi matematis siswa.

\section{KAJIAN LITERATUR}

\section{Komunikasi Matematis}

Komunikasi merupakan suatu keterampilan yang sangat penting dalam kehidupan manusia dan merupakan suatu alat bagi manusia untuk berhubungan dengan orang lain di lingkungannya baik secara verbal maupun tertulis. Komunikasi juga merupakan suatu keterampilan penting dalam pembelajaran matematika. Menurut The Intended Learning Outcomes dalam Purnama (2012: 78), komunikasi matematis yaitu kemampuan untuk mengekspresikan ide-ide matematika secara koheren kepada teman, guru, dan lainnya melalui bahasa lisan dan tulisan. Ini berarti dengan adanya komunikasi matematis guru dapat lebih memahami kemampuan siswa dalam menginterpretasikan dan mengekspresikan pemahamannya tentang konsep yang mereka pelajari.

Selain itu, NCTM (dalam Hendriana, 2017: 60) menyatakan bahwa komunikasi adalah salah satu kompetensi dasar matematis yang esensial dari matematika. Tanpa komunikasi yang baik, maka perkembangan matematika akan terhambat. Simbol merupakan lambang atau media yang mengandung maksud dan tujuan tertentu. Simbol komunikasi ilmiah dapat berupa tabel, bagan, grafik, gambar persamaan matematika, dan sebagainya.

Baroody (1993) menyatakan ada lima aspek komunikasi matematis, yaitu: 1) Representasi, diartikan sebagai membuat bentuk lain dari ide atau permasalahan. Representasi dapat membantu siswa menjelaskan konsep atau ide serta dapat meningkatkan fleksibelitas dalam menjawab soal matematika. 2) Menyimak (listening) dalam proses diskusi aspek mendengar salah satu aspek yang penting. Mendengar secara hati-hati terhadap pernyataan teman dalam suatu kelompok serta dapat membantu siswa mengkonstruksi lebih lengkap pengetahuan matematika dan mengatur strategi jawaban yang lebih efektif. 3) Membaca (reading), kemampuan membaca merupakan kemampuan yang kompleks, karena di dalamnya terkait aspek mengingat, memahami, membandingkan, menemukan, menganalisis, mengorganisasikan, dan akhirnya apa yang terkandung dalam bacaan. 4) Diskusi (discussing), merupakan sarana untuk mengungkapkan dan merefleksikan pikiran siswa. Beberapa kelebihan dari diskusi kelas, yaitu dapat mempercepat pemahaman materi pembelajaran dan kemahiran menggunakan strategi serta membantu siswa mengkonstruk pemahaman matematika. 5) Menulis (writing), kegiatan yang dilakukan dengan sadar untuk mengungkapkan dan merefleksikan pikiran (Hendriana, 2017). Apabila aspek-aspek ini dikuasai dengan baik, maka kemampuan komunikasi matematis pun dapat dicapai. Oleh sebab itu, seorang guru hendaknya memilih model ataupun pendekatan pembelajaran yang dalam penerapannya mengandung aspek-aspek komunikasi matematis, sehingga dapat membantu dalam mengasah kemampuan komunikasi matematis siswa.

Berdasarkan uraian komunikasi matematis tersebut dapat kita simpulkan bahwa komunikasi matematis kemampuan siswa untuk dapat mengomunikasikan ide-ide matematika mereka baik secara lisan maupun tulisan melalui penggunaan simbol, tabel, gambar, grafik atau diagram berdasarkan aspek-aspek komunikasi matematis tersebut.

Adapun indikator yang penulis gunakan dalam penelitian ini adalah indikator komunikasi matematis tulisan dengan memodifikasi indikator menurut Sumarmo (dalam Hendriana dan Soemarmo, 2014: 30) dan disesuaikan dengan indikator pembelajaran yaitu sebagai berikut: 
1. Mempresentasikan benda nyata, gambar, dan diagram ke dalam ide atau simbol matematika.

2. Menjelaskan ide, situasi dan relasi matematika secara tulisan dengan benda nyata, gambar, grafik, dan ekspresi aljabar.

3. Menyatakan peristiwa sehari-hari dalam bahasa atau simbol matematika.

\section{Pendekatan Reciprocal Teaching}

Reciprocal teaching merupakan satu pendekatan terhadap pengajaran siswa akan strategi-strategi belajar. Menurut Trianto (2007) reciprocal teaching adalah pendekatan konstruktivis yang berdasar pada prinsip-prinsip pembuatan/pengajuan pertanyaan. Dengan reciprocal teaching guru mengajarkan siswa mengembangkan keterampilan kognitif penting dengan menciptakan pengalaman belajar, melalui pemodelan perilaku tertentu dan kemudian membantu siswa mengembangkan keterampilan tersebut atas usaha mereka sendiri dengan pemberian semangat, dukungan dan suatu sistem scaffolding.

Sedangkan menurut Istarani dan Ridwan (2014) reciprocal teaching merupakan suatu penyampaian materi ajar dengan guru menunjuk seorang siswa untuk menggantikan perannya sebagai guru dan bertindak sebagai pemimpin diskusi dalam kelompok, yang sasarannya adalah mengajarkan empat strategi pemahaman pengaturan diri spesifik, yaitu perangkuman, pengajuan pertanyaan, pengklarifikasian, dan prediksi. Sedangkan guru beralih peran dalam kelompok sebagai motivator, mediator, pelatih memberikan dukungan, umpan balik, serta semangat bagi siswa.

Faradila (2016) menyatakan ada empat komponen dalam pendekatan Reciprocal Teaching, yaitu: 1) Membuat rangkuman (summarizing), dibutuhkan untuk dapat membedakan hal-hal yang penting dan hal-hal yang tidak penting, yakni menentukan intisari dari suatu teks bacaan. Sehingga dengan merangkum siswa betul-betul dapat memahami apa yang dipelajarinya. 2) Membuat pertanyaan (questioning), digunakan untuk memonitor dan mengevaluasi sejauh mana pengetahuan pembaca terhadap bahan bacaan. Siswa membuat soal yang tidak dipahami ataupun soal yang diajukan kepada diri sendiri kemudian menjawabnya. 3) Mengklarifikasi (clarifying), siswa diminta untuk mencerna makna dari kata-kata atau kalimat-kalimat yang tidak familiar, apakah mereka dapat memahami maksud dari suatu paragraf kemudian mengklarifikasi kata-kata atau kalimatkalimat yang masih asing/tidak familiar baginya. 4) Memprediksi (predicting), pada tahap ini pembaca diajak untuk melibatkan pengetahuan yang sudah diperolehnya dahulu untuk digabungkan dengan informasi yang diperoleh dari teks yang dibaca untuk kemudian digunakan dalam mengimajinasikan kemungkinan yang akan terjadi berdasarkan atas gabungan informasi yang sudah dimilikinya.

Dengan demikian dapat disimpulkan bahwa pendekatan reciprocal teaching adalah suatu pendekatan pembelajaran yang menekankan pada empat pemahaman mandiri siswa yaitu Summarizing (merangkum), Questioning (menanya), Clarifying (mengklarifikasi), dan Predicting (memprediksi). Komponen yang terdapat dalam pendekatan reciprocal teaching ini diantaranya merupakan aspek-aspek yang terdapat dalam kemampuan komunikasi matematis siswa sehingga dengan menerapkan pembelajaran dengan pendekatan reciprocal teaching dapat menjadikan siswa lebih aktif untuk mengkomunikasikan ide-ide matematisnya

Adapun langkah-langkah pendekatan Reciprocal Teaching adalah sebagai berikut: 1) Memilih materi pokok bahasan. 2) Menjelaskan tujuan pokok bahasan yang hendak dicapai. 3) Guru memotivasi siswa sehingga siswa senang dan lebih giat dalam mengikuti pembelajaran. 4) Guru membagikan lembar materi kepada siswa. 5) Guru memberitahukan kepada siswa pada tahap awal guru yang akan menjelaskan materi pelajaran dan untuk tahap berikutnya akan dipilih secara acak seorang siswa yang bertindak sebagai "siswa guru". 6) Guru meminta siswa membaca lembar materi dan memahaminya serta menandai bacaan atau bagian dari materi yang dianggap sulit atau 
kurang dimengerti. 7) Setelah selesai, guru memperagakan empat keterampilan yaitu merangkum, membuat soal, menjelaskan dan memprediksi suatu permasalahan. 8) Pada segmen ini guru memilih siswa secara acak untuk menjadi "siswa guru". Siswa yang ditunjuk tersebut akan menjelaskan kepada teman-temannya mengenai materi yang telah dirangkum dan menjelaskan soal-soal yang telah dikerjakannya serta memprediksi soal yang akan diberikan kepada temannya sesuai dengan materi yang dipelajari. Dengan demikian siswa lain memperhatikan. Hal ini dilakukan berulang sehingga setiap siswa mendapat minimal sekali menjadi "siswa guru". Dengan begitu siswa akan merasa menemukan sesuatu yang ada di luar dirinya dan cenderung untuk tampil maksimal agar mendapat pujian dari teman yang lain. 9) Guru dan siswa mengevaluasi proses penyelidikan yang telah dilakukan, merangkum hasil pelajaran yang telah diperoleh dan menyimpulkan materi. 10) Memberikan tugas kepada siswa (Risnawati, 2008).

Tabel 1. Fase-Fase Pendekatan Reciprocal Teaching

\begin{tabular}{|c|c|}
\hline No & Jenis Aktivitas Guru \\
\hline 1 & Guru menyampaikan tujuan dan materi pelajaran \\
\hline 2 & $\begin{array}{l}\text { Guru memberi motivasi dan menginformasikan bahwa pembelajaran yang akan } \\
\text { diterapkan yaitu Reciprocal Teaching }\end{array}$ \\
\hline 3 & $\begin{array}{l}\text { Guru meminta siswa membaca dan memahami bacaan pertama pada bahan bacaan } \\
\text { yang diberikan serta pada buku paket secara sendiri-sendiri }\end{array}$ \\
\hline 4 & $\begin{array}{l}\text { Memberikan kesempatan kepada siswa untuk meringkas atau merangkum materi } \\
\text { secara berkelompok pada LKS yang diberikan (Summarizing) }\end{array}$ \\
\hline 5 & Meminta siswa membuat pertanyaan dari materi yang tidak dimengerti (Questioning) \\
\hline 6 & $\begin{array}{l}\text { Guru berkeliling mengontrol, membimbing dan membantu siswa selama kegiatan } \\
\text { merangkum dan membuat pertanyaan }\end{array}$ \\
\hline 7 & $\begin{array}{l}\text { Menugaskan siswa untuk melakukan tahap-tahap Reciprocal Teaching pada bacaan } \\
\text { kedua dan memilih seorang siswa untuk menjadi "siswa guru" seperti yang telah } \\
\text { dilakukan guru pada bacaan pertama (Clarifying) }\end{array}$ \\
\hline 8 & Meminta siswa mengerjakan latihan pada LKS (Predicting) \\
\hline 9 & Mengkoordinir siswa untuk menyelesaikan dan membahas soal yang ada pada LKS \\
\hline 10 & $\begin{array}{l}\text { Memberikan motivasi kepada siswa yang kurang berpartisipasi aktif dengan } \\
\text { memberikan pujian }\end{array}$ \\
\hline 11 & $\begin{array}{l}\text { Menyimpulkan materi bersama siswa, mengadakan refleksi proses pembelajaran yang } \\
\text { telah dilakukan serta meminta siswa untuk mempelajari materi pelajaran selanjutnya }\end{array}$ \\
\hline
\end{tabular}

Pendekatan reciprocal teaching memiliki kelebihan dan kekurangan. Adapun kelebihannya, yaitu: 1) Dapat melatih kemampuan siswa belajar mandiri. 2) Selama kegiatan pembelajaran, siswa membuat rangkuman. Dengan demikian siswa terlatih untuk menemukan hal-hal penting dari apa yang dipelajari, sehingga dapat dikatakan bahwa reciprocal teaching dapat meningkatkan hasil belajar yang rendah. 3) Selama kegiatan pembelajaran, siswa membuat pertanyaan dan menyelesaikan pertanyaan. Sehingga reciprocal teaching dapat mempertinggi kemampuan siswa dalam berkomunikasi sekaligus memecahkan masalah.

Adapun kekurangan dari pendekatan reciprocal teaching ini, yaitu: 1) Kebanyakan siswa merasa takut diminta tampil didepan siswa lain. Siswa tersebut merasa tidak percaya diri ketika presentasi didepan kelas. 2) Waktu yang dibutuhkan untuk menerapka pendekatan reciprocal teaching ini cukup lama. Oleh karena itu, untuk mengatasi kekurangan ini maka peneliti membuat penerapan reciprocal teaching ini secara berkelompok sehingga anggota kelompok dapat memotivasi dan memberikan semangat bagi perwakilan kelompok untuk tampil di depan kelas. Sedangkan 
untuk meminimalisir waktu, pada kegiatan membaca peneliti menugaskan untuk membaca materi yang akan dipelajari dirumah terlebih dahulu kepada siswa.

\section{METODE}

Penelitian ini merupakan penelitian quasi eksperimen dengan The Nonequivalent Pretest-Posttest Control Group Design yang disajikan dalam tabel berikut:

Tabel 2. Desain Penelitian

\begin{tabular}{cccc}
\hline Kelompok & Pretest & Perlakuan & Posttest \\
\hline Eksperimen & $\mathrm{O}_{1}$ & $\mathrm{X}$ & $\mathrm{O}_{2}$ \\
\hline Kontrol & $\mathrm{O}_{3}$ & - & $\mathrm{O}_{4}$ \\
\hline
\end{tabular}

Adapun untuk skala kemandirian belajar siswa dibagi menjadi tiga tingkatan yaitu, tinggi, sedang dan rendah. Secara rinci rancangannya dapat dilihat pada tabel berikut:

\section{Tabel 3. Hubungan Pendekatan Pembelajaran Dan Kemandirian Belajar terhadap Kemampuan Komunikasi Matematis}

\begin{tabular}{cccc}
\hline Kemandirian Belajar $(B)$ & Tinggi & Sedang \\
Pendekatan Pembelajaran $(A)$ & $\left(b_{1}\right)$ & $\left(b_{2}\right)$ & $\begin{array}{c}\text { Rendah } \\
\left(b_{3}\right)\end{array}$ \\
\hline Reciprocal Teaching $\left(a_{1}\right)$ & $(a b)_{11}$ & $(a b)_{12}$ & $(a b)_{13}$ \\
\hline Konvensional $\left(a_{2}\right)$ & $(a b)_{21}$ & $(a b)_{22}$ & $(a b)_{23}$ \\
\hline
\end{tabular}

Populasi dalam penelitian ini adalah seluruh siswa SMP Negeri 2 Bangkinang Kota tahun pelajaran 2017/2018. Pengambilan sampel penelitian ini menggunakan teknik purposive sampling. Pengambilan sampel memperhatikan pertimbangan bahwa kelas yang dipilih adalah kelas yang pelajaran matematikanya diajar oleh guru yang sama. Selain itu, kemampuan komunikasi matematis setiap kelas yang diambil sebagai sampel penelitian adalah kelas-kelas dengan rata-rata nilai yang relatif sama serta kemandirian belajar yang tidak terlalu berbeda. Melalui proses tersebut, terpilihlah kelas VII-6 sebagai kelas eksperimen, yaitu kelas yang menggunakan pendekatan reciprocal teaching dan kelas VII-7 sebagai kelas kontrol, yaitu kelas yang mengunakan pembelajaran konvensional.

Sedangkan teknik pengumpulan data yang digunakan dalam penelitian adalah teknik tes, non-tes, dan observasi. Teknik tes berupa pemberian soal pretest dan posttest dengan menggunakan tes berbentuk uraian dengan cara memberikannya pada kedua kelas sampel sebelum dan setelah diberi perlakuan. Sebelum tes dilakukan, soal tes harus harus terlebih dulu diuji sehingga memenuhi beberapa syarat seperti validitas, reliabilitas, daya pembeda dan tingkat kesukaran soal. Berdasarkan hasil uji coba soal, dari 10 soal yang diuji cobakan diperoleh 8 soal yang layak digunakan dengan koefisien reliabilitas sebesar 0,912 dengan interpretasi sangat baik. Sedangkan teknik non-tes berupa pemberian angket kemandirian belajar yang diberikan sebelum dilakukan treatment yang terlebih dahulu diuji validitas dan reliabilitasnya, didapatkan koefisien reliabilitas sebesar 0,8651 dengan kategori baik, yang terdiri dari 32 pernyataan dengan 5 pilihan jawaban yaitu Sering Sekali (SS), Sering (SR), Kadang-kadang (KD), Jarang (JR), dan Jarang Sekali (JS).

Data yang dianalisis dalam penelitian ini adalah data kemandirian belajar dan data kemampuan komunikasi matematis yang diperoleh dari skor pretest, posttest dan gain. Teknik analisis data yang digunakan dalam penelitian ini adalah dengan tes- $t$ dan anova dua arah. Tes- $t$ adalah salah satu uji statistik yang digunakan untuk mengetahui ada atau tidaknya perbedaan yang 
signifikan dari dua variabel yang dikomparatifkan (Hartono, 2010: 178). Sedangkan uji anova dua arah digunakan untuk menguji hipotesis yang membandingkan perbedaan rata-rata dari sampel yang melibatkan dua faktor atau lebih (Lestari dan Yudhanegara, 2017: 308). Sebelum melakukan analisis data dengan tes-t, ada dua syarat yang harus dilakukan yaitu: uji normalitas dengan uji liliefors dan uji homogenitas dengan uji-F.

\section{HASIL DAN PEMBAHASAN}

\section{Hasil}

Berdasarkan hasil uji normalitas terhadap data kemandirian belajar dan data kemampuan komunikasi matematis, diperoleh simpulan bahwa data sampel dari kelas eksperimen dan kelas kontrol berasal dari populasi yang berdistribusi normal. Demikian pula hasil uji homogenitas variansi populasi, disimpulkan bahwa sampel berasal dari populasi yang homogen. Setelah dilakukan uji perbedaan dua rata-rata, diperoleh simpulan bahwa sampel dari kelas eksperimen dan kelas kontrol mempunyai kemandirian belajar dan kemampuan komunikasi matematis yang relatif sama, selanjutnya dilakukan uji hipotesis penelitian.

Berikut ini disajikan rangkuman hasil pengujian hipotesis dengan menggunakan uji-t pada hipotesis pertama untuk melihat perbedaan kelas sampel secara umum dan untuk hipotesis kedua dan ketiga menggunakan uji anova dua arah, yaitu rerata kemampuan komunikasi matematis siswa berdasarkan pendekatan pembelajaran yaitu pendekatan Reciprocal Teaching dan Konvensional ditinjau dari kemandirian belajar siswa kategori tinggi, sedang, dan rendah.

Tabel 4. Rekapitulasi Hasil Uji-t Posttest

\begin{tabular}{ccc}
\hline $\boldsymbol{t}_{\text {hitung }}$ & $\boldsymbol{t}_{\boldsymbol{t a b e l}} \mathbf{5} \%$ & Keterangan \\
\hline 3,53 & 2,01 & $\mathrm{H}_{\mathrm{a}}$ diterima \\
\hline
\end{tabular}

Tabel 5. Rekapitulasi Hasil Analisis Anova Dua Arah

\begin{tabular}{ccccccc}
\hline Sumber & $\boldsymbol{J K}$ & $\boldsymbol{d} \boldsymbol{k}$ & $\boldsymbol{R K}$ & $\boldsymbol{F h}$ & $\boldsymbol{F t}$ & Kep. Uji \\
\hline $\begin{array}{c}\text { Pendekatan } \\
\text { Pembelajaran }(A)\end{array}$ & 2541,05 & 1 & 2541,05 & 24,65 & 4,05 & $H_{a}$ diterima \\
\hline $\begin{array}{c}\text { Kemandirian } \\
\text { Belajar }(B)\end{array}$ & 5043,71 & 2 & 2521,86 & 24,46 & 3,20 & $H_{a}$ diterima \\
\hline Interaksi $(A B)$ & 291,43 & 2 & 145,72 & 1,41 & 3,20 & $H_{a}$ ditolak \\
\hline
\end{tabular}

Berdasarkan hasil analisis uji hipotesis pada uji-t dan anova dua arah dengan taraf signifikansi 5\% diperoleh sebagai berikut:

1. Berdasarkan hasil analisis data menggunakan uji-t, dapat dilihat pada tabel 4 diperoleh nilai $t_{\text {hitung }}$ lebih besar daripada $t_{\text {tabel }}(3,53>2,01)$. Dengan demikian, Ha diterima dan Ho ditolak. Selanjutnya dilihat dari perbedaan mean kelas eksperimen dan kelas kontrol yaitu kelas eksperimen yang menggunakan pendekatan reciprocal teaching adalah 78,12 dan kelas kontrol yang menggunakan pembelajaran konvensional adalah 64 menunjukkan mean kelas eksperimen lebih tinggi dari mean kelas kontrol. Hal ini menunjukkan bahwa terdapat perbedaan antara kemampuan komunikasi matematika siswa yang menggunakan pendekatan pembelajaran reciprocal teaching dengan siswa yang belajar menggunakan pembelajaran konvensional. Selain itu, berdasarkan perhitungan uji N-Gain di dapat rata-rata N-gain untuk 
kelas eksperimen sebesar 0,7022 dengan kategori tingi sedangkan rata-rata $\mathrm{N}$-gain untuk kelas kontrol sebesar 0,4914 dengan kategori sedang. Hal ini dapat disimpulkan bahwa penerapan pendekatan reciprocal teaching dalam pembelajaran matematika memiliki pengaruh positif terhadap kemampuan komunikasi matematis siswa. Hal ini sejalan dengan penelitian Rachmayani (2014) terhadap siswa kelas VII SMP, dimana diperoleh bahwa kemampuan komunikasi matematis siswa yang diberikan pembelajaran reciprocal teaching lebih tinggi dari siswa yang diberikan pembelajaran langsung. Hasil analisis juga sejalan dengan penelitian Dwi Rifa (2016) diperoleh bahwa pembelajaran reciprocal teaching berpengaruh terhadap kemampuan komunikasi matematis siswa.

2. Berdasarkan hasil analisis data menggunakan uji anova dua arah, dapat dilihat pada tabel 5 diperoleh nilai $\mathrm{F}(\mathrm{B})_{\text {hitung }}=24,46>\mathrm{F}(\mathrm{B})_{\text {tabel }}=3,20$ pada taraf signifikan $5 \%$ yang berarti $\mathrm{H}_{\mathrm{a}}$ diterima. Hal ini menunjukkan bahwa terdapat perbedaan kemampuan komunikasi matematis antara siswa yang memiliki kemandirian belajar tinggi, sedang dan rendah. Berdasarkan rata-rata kemampuan komunikasi matematis untuk tiap kategori kemandirian belajar siswa yang diajar dengan pendekatan reciprocal teaching dan pembelajaran konvensional menunjukkan hasil yang berbeda. Pada kategori kemandirian belajar tinggi, siswa kelas eksperimen dan kontrol berturut-turut mendapatkan rata-rata sebesar 88,75 dan 85,67. Kemudian pada kategori sedang, mendapatkan rata-rata sebesar 77,24 dan 68,06 serta untuk kategori kemandirian belajar rendah, mendapatkan rata-rata sebesar 71,25 dan 41,67. Dengan demikian dapat disimpulkan bahwa jika ditinjau dari kemandirian belajar, terdapat perbedaan kemampuan komunikasi matematis antara siswa yang diajar dengan pendekatan Reciprocal Teaching dan siswa yang diajar dengan pembelajaran konvensional.

3. Berdasarkan hasil analisis data menggunakan uji anova dua arah, dapat dilihat pada tabel 5 diperoleh nilai $\mathrm{F}(\mathrm{A} \times \mathrm{B})_{\text {hitung }}=1,41<\mathrm{F}(\mathrm{A} \times \mathrm{B})_{\text {tabel }}=3,20$ pada taraf signifikan $5 \%$. Berarti $\mathrm{H}_{0}$ diterima dan $\mathrm{H}_{\mathrm{a}}$ ditolak. Sehingga menunjukkan bahwa tidak terdapat interaksi antara faktor pendekatan pembelajaran dan faktor kemandirian belajar dalam mempengaruhi kemampuan komunikasi matematis siswa. Dengan demikian, pendekatan pembelajaran bersama-sama dengan kemandirian belajar tidak mempengaruhi kemampuan komunikasi matematis siswa sehingga analisis pasca Anova tidak dilanjutkan.

\section{Pembahasan}

Berdasarkan hasil yang telah dipaparkan sebelumnya, dapat dilihat adanya perbedaan kemampuan komunkasi matematis antara siswa yang diajar dengan menggunakan pendekatan Reciprocal Teaching dan siswa yang diajar dengan pembelajaran konvensional, dengan hasil dari perhitungan uji-t diperoleh $t_{\text {hitung }}=3,53$ lebih besar dari $t_{\text {tabel }}=2,01$ pada taraf signifikan $5 \%$ sehingga $3,53>2,01$ atau $t_{\text {hitung }}>t_{\text {tabel }}$ sehingga $H_{a}$ diterima dan $\mathrm{H}_{0}$ ditolak.

Jika ditinjau dari kemandirian belajar, terdapat perbedaan kemampuan komunikasi matematis antara siswa yang diajar dengan pendekatan Reciprocal Teaching dan siswa yang diajar dengan pembelajaran konvensional. Hasil dari perhitungan uji anova dua arah diperoleh $\mathrm{F}(\mathrm{B})_{\text {hitung }}=24,46>\mathrm{F}(\mathrm{B})_{\text {tabel }}=3,20$ pada taraf signifikan $5 \%$ yang berarti $\mathrm{H}_{\mathrm{a}}$ diterima dan $\mathrm{H}_{0}$ ditolak. Hal ini menunjukkan bahwa terdapat perbedaan kemampuan komunikasi matematis antara siswa yang memiliki kemandirian belajar tinggi, sedang dan rendah.

Tidak terdapat interaksi antara faktor pendekatan pembelajaran dan faktor kemandirian belajar dalam mempengaruhi kemampuan komunikasi matematis siswa. Dengan kata lain, pendekatan pembelajaran bersama-sama dengan kemandirian belajar tidak mempengaruhi kemampuan komunikasi matematis siswa. Hasil perhitungan menggunakan uji anova dua arah diperoleh diperoleh nilai $\mathrm{F}(\mathrm{A} \times \mathrm{B})_{\text {hitung }}=1,41<\mathrm{F}(\mathrm{A} \times \mathrm{B})_{\text {tabel }}=3,20$ pada taraf signifikan 
5\%. Hal ini berarti hipotesis yang menyatakan $\mathrm{H}_{0}$ diterima, artinya tidak terdapat interaksi antara pendekatan pembelajaran dan kemandirian belajar.

Jadi, dapat disimpulkan bahwa terdapat pengaruh penerapan pendekatan reciprocal teaching terhadap kemampuan komunikasi matematis ditinjau dari kemandirian belajar siswa. Selanjutnya, peneliti merekomendasikan pendekatan reciprocal teacbing dapat dijadikan sebagai salah satu alternatif strategi pembelajaran pada mata pelajaran matematika.

Pada penelitian ini masih banyak kelemahan dan keterbatasan yang sulit dikendalikan. Adapun keterbatasan pada saat penelitian, yaitu dalam penerapannya, reciprocal teaching ini membutuhkan waktu yang cukup lama sehingga diharapkan pada peneliti selanjutnya untuk dapat menggunakan waktu dengan maksimal. Sebagai saran, pada kegiatan membaca bisa dengan menugaskan siswa untuk membaca dirumah terlebih dahulu sehingga ketika di sekolah siswa hanya perlu mengulang bacaan saja. Namun demikian, keterbatasan penelitian ini tidak mengurangi kebenaran hasil penelitian yang diperoleh, sehingga dapat dipergunakan dalam meningkatkan kemampuan komunikasi matematis siswa menjadi lebih baik.

\section{REFERENSI}

Agustyaningrum, Nina. (2011). Implementasi Model Pembelajaran Learning Cycle 5E Untuke Meningkatkan Kemampuan Komunikasi Matematis Siswa Kelas IX B SMP Negeri 2 Sleman. Prosiding Jurusan Pendidikan Matematika, Universitas Negeri Yogyakarta ISBN : 978 $979-16353-6-3$ : tidak diterbitkan.

Bistari. (2010). Pengembangan Kemandirian Belajar Berbasis Nilai untuk Meningkatkan Komunikasi Matematik. Jurnal Pendidikan Matematika dan IP A Universitas Tanjungpura. 1, (1), 11-12.

Faradila, dkk. (2016). Eksperimentasi Pendekatan Pembelajaran Reciprocal Teaching dengan Alat Peraga Pada Pokok Bahasan Lingkaran ditinjau dari Kreativitas Siswa. Jurnal tidak diterbitkan Elektronik Pembelajaran Matematika FKIP Universitas Sebelas Maret Surakarta, Vol.4 No. 3 ISSN: 2339-1685

Hartono. (2010). Statistik untuk Pendidikan. Yogyakarta: Pustaka Pelajar.

Hendriana, Heris dan Utari Soemarrmo. (2014). Penilaian Pembelajaran Matematika,. Bandung: Refika Aditama

Hendriana, Heris, Euis Eti Rohaeti dan Utari Sumarmo. (2017). Hard Skills dan Soft Skills Matematik Siswa. Bandung: Refika Aditama.

Istarani dan Muhammad Ridwan. (2014). 50 Tipe Pembelajaran Kooperatif. Medan: Media Persada.

Lestari, Karunia Eka dan Mokhammad Ridwan Yudhanegara. 2015. Penelitian Pendidikan Matematika. Bandung: Refika Aditama.

Palinscar \& Brown. (1984). Reciprocal Teaching of Comprehension-Fastering And Comprehension-Monitoring Activities. Journal of Cognition And Instruction, p. 117-175. Michigan: Michigan State University. 
Permendikbud. (2014). Standar Isi Kurikulum 2013 Untuk Satuan Pendidikan Dasar dan Menengah No. 58.

Qohar, Abd. (2010). Mengembangkan Kemampuan Pemahaman, Koneksi dan Komunikasi Matematis Serta Kemandirian Belajar Matematika Siswa SMP Melalui Reciprocal Teaching. Disertasi Universitas Pendidikan Indonesia: tidak diterbitkan.

Rachmayani, Dwi. (2014). Penerapan Pembelajaran Reciprocal Teaching untuk Meningkatkan Kemampuan Komunikasi Matematis Dan Kemandirian Belajar Matematika Siswa. Jurnal Pendidikan UNSIKA. 2, 13-23 ISSN 2338-2996.

Ramellan, Purnama. (2012). Kemampuan Komunikasi Matematis dan Pembelajaran Interaktif. Jurnal Pendidikan Matematika FMIPA UNP, Vol. 1 No. 1 Part 2: tidak diterbitkan.

Rifa, Dwi, Yulis Jamiah, dan Ahmad Yani. (2016). Pengaruh Pembelajaran Reciprocal Teaching terhadap Kemampuan Komunikasi Matematis Siswa pada Materi Segiempat di SMP.. Jurnal Pendidikan matematika FKIP Untan Pontianak. 5, (6), 1-10.

Risnawati. (2008). Strategi Pembelajaran Matematika. Pekanbaru: Suska Pers.

Trianto. (2007). Model-Model Pembelajaran Inovatif Berorientasi Konstruktivistik. Jakarta: Prestasi Pusaka.

Van de Walle, John A. (2006). Matematika Sekolah Dasar dan Menengah. Jakarta: Erlangga. 